\title{
Brand V/S Generic- Value Based Pricing for Pharmaceuticals in India
}

\author{
Anantha Naik Nagappa*, Kavya H B, Vinuth Chikkamath and Vaishnavi Naik \\ SCS College of Pharmacy, India
}

Submission: September 16, 2017; Published: October 16, 2017

*Corresponding author: Anantha Naik Nagappa, SCS College of Pharmacy, Harapanahalli-583131, Karnataka, India Email: anantha1232000@gmail.com

\section{Abstract}

Indian Pharma industry has champion, as the manufacture of most cost effective formulations in the world. India, manufactures variety of formulations and exports all over the world. Recently, India has entered North America, Europe, and Japan with highly regulated markets across the globe. India's pharmaceutical exports stood at US $\$ 16.4$ billion in 2016-17 and are expected to grow by 30\% over the next three years to reach US $\$ 20$ billion by 2020, according to the Pharmaceuticals Export Promotion Council of India (PHARMEXCIL). The India scientists although not engaged in drug discovery, but are very much successful in introducing the Novel Drug Delivery System (NDDS) and Biotherapeutics, Biosimilars and Biobetters. The SWOT analysis of Indian Pharma industry indicates the strength in formulation, chief scientific, human resource and encouragement by foreign and local body. The weakness is active pharmaceutical ingredient dependence on China. Opportunities include access to the global market, regulatory offices of USFDA and other regulatory bodies in India. Threat includes the malpractices by Pharma industries identified by regulatory bodies. Despite of all this, Indian Pharma industries generic and brand medicines are showing the growth past six years. In this article, detailed analysis of the market structure and social economic culture of pharmaceutical industry are described.

Keywords: Generic medicines; Brand medicines; Health insurance; intellectual property rights

\section{Introduction}

The pharmaceuticals in its widen scope means drugs, diagnostics and other commodities that are used to treat disease, manage the condition along with tools and system which are used to diagnose the disease [1]. The pharmaceuticals are the result of extensive research effort which is usually governed by the Intellectual Property Rights (IPR). The IPR is protected by registering the pharmaceuticals as patent trademark franchise. The pharmaceuticals which are protected by patents usually for 20 years from the date of registration. The patent period is protected during which no one can else manufacture the products without the permission of the patent holder. The patent holder shall loose the authority over the patent, after the date of patent period gets over. Anybody can make the patented product, including innovator after patent regimen over and sell it in the market such an innovator product is called "Generics" [2].

Generics are considerably lower in price than the brand and are likely to give a tough price competition to the innovator brand, hence the innovator will reduce or the innovator can release the generic version of the innovator brand. The generics are usually considered as equivalent to innovator brand in all aspects, especially in bio availability and bio equivalence (BA/ $\mathrm{BE}$ ). It is presumed the generic version shall be equipotent as brand medicines. The Indian pharmaceutical sector is one of the largest manufacturer and supplier of generics version of the medicine across the world North America, European Union, United Kingdom, Japan and Australia. The countries of North America, European Union, Great Britain along with Japan and Australia are highly regulated markets. They are quality conscious and are committed to see that citizen of that country shall get the standard medicines; hence the regulatory agencies are proactive and usually scrutinize the quality of the products meticulously. The regulatory agencies have set standards for not only the products, but also the process of manufacturing facility and human resource. The regulatory agencies send their inspection team to get ascertain the product is manufactured as per the set standard by the regulatory agencies [3].

The generic drugs once get approved licenses to sell in the developed country. The product in the market begins to compete with innovator brand. The innovator brand which is expensive compare to generic looses the market share giving way for the development of generic medicines. This is mainly happening due to support of Health Insurance Company and government. The 
Health Insurance Company may put a condition to reimburse the prescriptions for generic medicines instead of innovator brand. Insurance company wants to save money by adapting generic medicine, government may also provide in its health care facility for the government and public out of budgetary allocations [4].

In India, the definition of generic medicine is different from that of developed countries. The criteria of BA/BE is not applicable in India for generic medicine. The qualitative differentiation from the registered brand is based on price differential, the bulk packing, and least promotional expenditures. The label of the generic medicines shall be the name of the drug mentioned in Pharmacopeia. For example Paracetamol Tablet IP, Aspirin Tablet IP. The Products are not heavily promoted but are sold as bulk packages which are meant for Over the Counter sales like OTC to dispense in medical shops and hospitals. The generic medicines we also be identified by the companies who make cheap medicines compared to other products in the market for example Mankind, Mylan, Apotex, Lupin etc. However they are cheaper do not contain a brand name and does not have a highly attractive packaging and other feature they are not marketed extensively like a brand products. They are not promoted, hence the marketing expenses are kept as low as possible they may not be sold in scheme. The idea is to give tough price competition to the branded medicine. They are usually bulk packed and supply to the government hospitals, primary health care centres and dispensed to the patient directly [5] (Table 1) [6-9].

Table 1: Shows the price comparisons of Generic and Brand medicines in India of various therapeutic categories [6-9].

\begin{tabular}{|c|c|c|c|c|c|c|}
\hline Sl.No & Class of the Drugs & $\begin{array}{l}\text { Name of the } \\
\text { Drugs }\end{array}$ & $\begin{array}{c}\text { Therapeutic } \\
\text { Category }\end{array}$ & $\begin{array}{l}\text { Brand Medicine } \\
\text { Price (Rs) }\end{array}$ & $\begin{array}{c}\text { Generic Medicine } \\
\text { Price }\end{array}$ & $\begin{array}{c}\text { Price Difference } \\
\text { (Rs) }\end{array}$ \\
\hline 1 & Biguanides & Metformin & Antidiabetic & 22.6 & 5.15 & 17.45 \\
\hline 2 & $\begin{array}{l}\text { Calcium channel } \\
\text { blockers }\end{array}$ & Amlodipine & $\begin{array}{c}\text { Cardiovascular } \\
\text { drugs }\end{array}$ & 64.5 & 2.68 & 61.82 \\
\hline 3 & Cephalosporin & $\begin{array}{l}\text { Ceftriaxone + } \\
\text { Sulbactam }\end{array}$ & Antibiotics & 132.5 & 15 & 117.5 \\
\hline 4 & Fluroquinolones & Ciproflaxacin & Antibiotics & 129 & 22 & 107 \\
\hline 5 & H2 blockers & Ranitidine & $\begin{array}{l}\text { Reduction of } \\
\text { gastric acid } \\
\text { secretion }\end{array}$ & 9 & 6.39 & 2.61 \\
\hline 6 & Macrolide & Azithromycin & Antibiotics & 128 & 86 & 42 \\
\hline 7 & $\begin{array}{c}\text { NSAIDs (Non steroidal } \\
\text { anti-inflammatory } \\
\text { drugs) }\end{array}$ & Paracetamol & $\begin{array}{c}\text { Antipyretic and } \\
\text { Analgesic }\end{array}$ & 11 & 2.45 & 8.55 \\
\hline 8 & Penicillin & Amoxicillin & Antibiotics & 128 & 26.25 & 101.75 \\
\hline 9 & Proton pump inhibitor & Pantoprazole & $\begin{array}{l}\text { Reduction of } \\
\text { gastric acid } \\
\text { secretion }\end{array}$ & 55 & 7.2 & 47.8 \\
\hline
\end{tabular}

One US dollar $=64.14$ Rs INR.

\section{Issues in brand medicines}

The brand medicines in India are registered with the different state government drug controlled department of each state, after verifying the mandatory data gives license for the product to be marketed all across the India by their brand name. So there are multiple licensing authorities who can give the license to the branded medicines all across India. This gives an advantage for the brand manufacturer who registers the product in one state and sells the product anywhere in the country. Many of the manufactures do not have the capacity to manufacture for whole of the India and restrict their marketing activity for three or four states. It is reported that more than 1 lakh brand medicines registered in the country. These brands are made up of nearly 600 pharmacopeia ingredients. Usually in a developed country only innovator is allowed to register a brand and rest of others has to serve the approved after the expiry of the patent period. The brand medicines in India are usually Me-too combinations and Table 2 contains the survey in the market. These numbers of brands has a negative impact on the health care practice and are creating problems. "Look alike and sound alike" brand names are causing many medication errors and duplications in prescriptions and patient safety is endangered. Apart from this every company has predetermined the resolution to push the product in the market, as a huge problem of waste inventory and incurring loss on capital, due to humiliation of the products which gets expired. The retail pharmacists are facing the crisis of competition within and by the doctors. The doctors in order to get additional income and indulge in buying particular brand medicines which is available with the doctor alone. Hence there is less prescription for the retail pharmacies [10] (Table 2) [11$14]$. 
Table 2: Shows the number of brand drugs in India [11-14].

\begin{tabular}{|c|c|c|}
\hline Sl.No & Name of the Drugs & Number of Brands \\
\hline 1 & Paracetamol & 90 \\
\hline 2 & Metformin & 258 \\
\hline 3 & Amolodipine & 293 \\
\hline 4 & Pantoprazole & 163 \\
\hline 5 & Ranitidine & 96 \\
\hline 6 & Glimepiride & 432 \\
\hline 7 & Aceclofenac & 339 \\
\hline 8 & Amoxicillin & 165 \\
\hline 9 & Loperamide & 9 \\
\hline 10 & $\begin{array}{c}\text { Codeine and } \\
\text { combinations }\end{array}$ \\
\hline
\end{tabular}

They are nearly one lakh brands registered and licensed for marketing across India. This has created turmoil in the pharmaceutical market. The pharmaceutical manufacturers are categorized as small scale, middle scale and large scale manufacturers. Small scale manufactures limits their marketing activity to a regional areas, for example the manufacturer may marketing his product district part of the state. Whereas the medium scale manufacturers are may be marketing the products in a region such as South Indian states or North Indian states. While the large manufactures are shall be marketing all across India with a proper marketing network. The large scale manufacture has to compete with their products of small scale and medium scale manufactures. Apart from price competition, pharmaceuticals of large manufactures have issues in logistics cold chain supply and price competition.

Medicines are striving hard and seem to be having the patronage of doctors, drugstore owners. The doctors preferred brand medicine because they believe brand medicines are Table 3: Shows the Generic and their launch date [17-20]. best in quality in comparison to generics. Brand medicines are promoted by means of incentives, gifts and as well constant campaign by detailing the chemist prefer to sell brand medicines as they given a better margin, and bringing good profits along with a good sale scheme like buy ten get five free [15].

\section{Issues with generic medicines}

Generic medicines have remained less popular and kept a low profile in the pharmaceutical market. They are less visible in the open market like chemist and druggist, although they are cheap in price their cheapness is associated with poor quality perception and generic medicines came into prominence. When the government of India in 2008 launched the "JAN AUSHADHI SCHEME" in this scheme the government is committed to develop generic medicines as an alternative to brand medicines. The generic medicines are to be manufactured by public sectors like Hindustan antibiotics limited and other state own public sectors like Karnataka antibiotics private limited etc. The main intention of the government is to address the issue of high expenses of medicines and improve the accessibility by bringing down the prices and affordability. The government of India under the ministry of chemical and fertilizers launched 'Jan Aushadhi Act in 2008'. Recently it became into prominence and renamed as "Prime Minister Jan Aushadhi Kendra" by getting the patronage of Prime Minister Office. The promotion of "JAN AUSHADHI KENDRA" along with proclamation and warning to doctors to write the prescription medicines in generic name with Capital letters has been shocking event like demonetization. The government pushing the head to the promotion of Generic medicines. By making it mandatory to write the prescription in generic names this is considered as a jolt and threat to the Business market in India.

\begin{tabular}{|c|c|c|c|}
\hline Sl.No & Name of the Manufacturer & Name of the Drugs & Date of launch \\
\hline 1 & Lupin & Bupropion (Wellbutrin) & $15-$ Jun-17 \\
\hline 2 & Mankind & Azilsartan & $17-$ May-17 \\
\hline 3 & Dr Reddy's Lab & Sofosbuvir & 15 -May-17 \\
\hline 4 & Sanofi & Lyxumia and Zemiglo & 21 -Dec-15 \\
\hline 5 & Cipla & Hepcvir-L & 1 -Dec-15 \\
\hline 6 & Cipla & Efavirenz & 15 -Nov-15 \\
\hline 7 & Ajanta Pharma & Sontelukast & $17-$ Mar-15 \\
\hline 8 & Zydus & Sofosbuvir & $30-$ Mar-15 \\
\hline 10 & Strides & Novoeight & $26-$ Apr-16 \\
\hline
\end{tabular}

The brands are launched empowered and constantly sustained by conscious effort and strategic planning by the company each brand is ranked as per the reviews generate for the company in every 3, 6 and 12 months. The product cycle is explains best usually the launch, development sustains and exit of the brand the best performing brands are called as cash cows as they generate huge profit for the company. The company invests huge money on human resource, and best effort towards the growth of the brand, in case the brand starts dealing in terms of sales then the company in the industry starts thinking above how to improve the sales, what are the regions for decline it may be due to competition/ technological breakthrough the 
consumer preferences accordingly industry makes appropriate strategic stages so that the brand span gets extended [16] (Table 3) $[17-20]$.

There is an open outcry that pharmaceutical industry, indulging unethical marketing practices in the absence of

Table 4: Show most widely abused prescription drugs and the consequences on Public health [21-26]

\begin{tabular}{|c|c|c|c|}
\hline Sl.No & Prescription Medicines & Off Label Uses & Consequences \\
\hline 1 & Clonidine & $\begin{array}{c}\text { Attention deficit hyperactivity } \\
\text { disorder }\end{array}$ & Jittery behavior, Irritability \\
\hline 2 & Colchicine & Pericarditis & Rhabdomyolysis \\
\hline 3 & Memantine & obsessive-compulsive disorder & Confusion \\
\hline 4 & Modafinil & Depression & Headaches, Nervousness \\
\hline 5 & Nadolol & Migraine & Dizziness, Bradycardia \\
\hline 6 & Naltrexone & Behavioral Addiction & Insomnia, Anxiety \\
\hline 7 & Propranolol & Performance Anxiety & Angina \\
\hline 8 & Quetiapine & Insomnia & Diabetes, Obesity, Hyperlipidemic \\
\hline 9 & Sildenafil & Female Sexual Arousal Disorder & $\begin{array}{l}\text { Myocardial infarction, Headache } \\
\text { and Flushing }\end{array}$ \\
\hline
\end{tabular}

The medicines are having multiple effects on all the organs, and cells they come across and are capable of causing Physiological, biochemical and Pharmacological influences, and capable of influencing the parameters of health. Drug effects are usually classified as therapeutic effects and side effects. Further side effects are usually classified as tolerable, adverse drug reactions (ADRs) and idiosyncratic effect. For example, Penicillin is used for treating the gram positive infections, although most of the side effects of Penicillin are tolerable but Penicillin shock which is dangerous enough to cause the death of the individual is a most feared ADRs in order to identifying and certain Penicillin allergy. The test dose of the Penicillin should be administered to the patient intradermally. If the skin allergic manifest, then Penicillin should not be given, as many alternative antibiotics available for treating the patients. Many drugs are capable of causing injury if in a case dose levels are not monitored, if the dose level of Nephrotoxic drug like NSAIDs, Amoxicillin, Amino glycosides Antibiotics are known to cause damage to Kidney. It is necessary to document and audit the prescription throughout the country on Pharmacovigilance programme in India (PVPI). The political will of government, to make it mandatory the preference of generic medicines versus brand medicines by central government has made the Pharmaceutical industry, a health care Practitioners, chemist and druggist into a difficult situation. The political will of the government is rising day by day and all the mention stake holders, Pharmaceutical industry, Doctors, Chemist and Druggist displaced by various means and modes. The doctors made hear and cry about the government direction, to ban the prescription in brand names documentation and regulation of prescription. It is very difficult to pinpoint any such laws by prescriber/Pharmaceutical industry. The drug utilization studies and audit of prescription can only identify such malpractice and may be able to change the irrational prescription of medicines to the public (Table 4) [21-26]. and insisting them to write generic names. Chemist and druggist are also openly expressed that they will be great financial loss, as margins of profit could be reduced by selling generic medicines instead of brand medicine. Pharmaceutical industry as appeal to the government not to strictly ban brand medicines in favour of the generic medicines $[27,28]$.

\section{Health insurance}

In India, the penetration of insurance sector in health is very low, less than $20 \%$, and the patients end up with payments of health expenditure and out-of-Pocket model. The out-of-Pocket model suitable for small expenditure involving short term illness, however expenditure for chronic disease, higher tertiary care and other health expensive health care expenditure need to be covered by either health insurance/by government subsides majority of the people/either below poverty line/middle class the problem with health insurance is addressed by modal regulatory agency like Insurance regulatory and development authority (IRDA). It has frame guidelines for administration of health insurance scheme in private sector. There are many private players offering variety of health insurance scheme to the public. Despite of health insurance scheme available, Indian public is not showing initially to adopt health insurance in large scale. Hence majority of the people are under out-of-Pocket payments model. The promotion of the generics shall be getting a kick start, if the patients are covered by health insurance. The insurance provider would be monitoring the prices of the medicine prescription by the doctors to the policy holders. Doctors are made to write generic medicine instead of expensive brand medicine for the patients [29,30] (Table 5) [31,32]. 
Table 5: Health insurance companies /providers in India [31-32].

\begin{tabular}{|c|c|}
\hline Sl. No & Health Insurance Companies/Providers \\
\hline 1 & Apollo DKV Insurance company Ltd. \\
\hline 2 & Aviva Life Insurance \\
\hline 3 & Bajaj Allianz General Insurance Co. Ltd. \\
\hline 4 & Birla Sun Life Insurance \\
\hline 5 & Family Health Plan Limited \\
\hline 6 & Future General India Insurance Company Limited \\
\hline 7 & HSBC Health Insurance \\
\hline 8 & HDF ERGO General Insurance Co Ltd \\
\hline 9 & The New India Assurance Co Ltd \\
\hline 10 &
\end{tabular}

In recent years, biological based treatments were introduced in various therapeutic segments from Cancer to Rheumatoid arthritis, and many more Biotherapeutics were less harmful than conventional small molecule drugs/medicine. They are safe and effective, unlike small chemical base molecule which are not safe but efficacious. Biotherapeutics limitation is its price, they are exorbitantly expensive and it becomes very difficult to use them in routine practice. The major issue of Biotherapeutics is its prohibitive cost which was address by preparing generic version of Biotherapeutics. The issues for biogenerics are pricing and difficulty in establishing similar structure as original brand, it is also not possible to have exact BA/BE profile which was possible for chemical based small molecule drugs. The price of biogenerics is currently as high as biological (Table 6).

Table 6: Biogenerics manufactures from India.

\begin{tabular}{|c|c|c|c|}
\hline Sl. No & Biogeneric & Company & Year of Launch \\
\hline \multirow{3}{*}{1} & \multirow{3}{*}{ Insulin } & Biocon & 2004 \\
\hline & & Wockhardt & 2003 \\
\hline & & Shreya Life Sciences & 2004 \\
\hline \multirow{3}{*}{2} & \multirow{3}{*}{ Streptokinase } & Bharat Biotech & 2003 \\
\hline & & Shantha Biotechnics & 2004 \\
\hline & & Cadila Pharmaceuticals & 2004 \\
\hline \multirow{6}{*}{3} & \multirow{6}{*}{ Erythropoietin } & Emcure & 2001 \\
\hline & & Ranbaxy & 2003 \\
\hline & & Hindustan Antibiotics & 2000 \\
\hline & & Intas Pharmaceutical & 2005 \\
\hline & & Shantha Biotechnics & 2005 \\
\hline & & Wockhardt & 2001 \\
\hline \multirow{6}{*}{4} & \multirow{6}{*}{ Hepatitis B vaccine } & Shantha Biotechnics & 1997 \\
\hline & & Bharat Biotech & 1998 \\
\hline & & Panacea Biotech & 2000 \\
\hline & & Wockhardt & 2000 \\
\hline & & Serum institute of India & 2001 \\
\hline & & Biological E & 2004 \\
\hline 5 & Interferon alpha- $2 \mathrm{~b}$ & Shantha Biotechnics & 2002 \\
\hline \multirow{2}{*}{6} & \multirow{2}{*}{ Granulocyte colony stimulating factor (G-CSF) } & Dr Reddy's Laboratories & 2001 \\
\hline & & Intas Pharmaceuticals & 2004 \\
\hline
\end{tabular}

Personalize medicine becomes reality when Lab-on-a-chip was introduced, here the technology involves bio specimen of an individual whose large nor DNA copies are made by polymerize chain reaction (PCR). These DNA molecules were tested in vitro/ in vivo by exposing the drug molecules to find out the extent of bioavailability in an individual. Along with pharmacokinetic $\left(\mathrm{P}_{\mathrm{k}}\right)$, for example, we can find out the responsiveness of diabetic patients for met form in. It is evident that each patient behaves uniquely in metabolism of drugs we can identify and use this information for treatment of this condition. Hence we can economize and enhance safety levels along with efficacy outcomes for patients. The generics can be compared with the brands to decide upon the value of generics in terms of safety, efficacy and the amount saved for the system and individual patients [33].

\section{References}

1. Nilesh Z, Sandeep F (2002) Patents and the Indian Pharmaceutical Industry. Business Briefing Pharma Tech, pp. 42-46.

2. Saha CN, Bhattacharya S (2011) Intellectual property rights an overview and implications in pharmaceutical industry. J Adv Pharm Techno Res 2(2): 88-93. 
3. Midha KK, McKay G (2009) Bioequivalence its History Practice and Future. AAPS J 4(11): 664-670.

4. Hassali MA, Alrasheedy AA, McLachlan A, Nguyen TA, Al-Tamimi SK, et al. (2014) The experiences of implementing generic medicine policy in eight countries a review and recommendations for a successful promotion of generic medicine use. Saudi Pharm J 22(6): 491-503.

5. Dunne SS, Cummins NM, Hannigan A, Shannon B, Dunne C, et al. (2013) Generic medicines: an evaluation of the accuracy and accessibility of information available on the internet. BMC Med Inform Decis Mak 13: 115

6. http://www.mapsofindia.com/my-india/society/generic-drugs-inindia-more-awareness-required

7. http://janaushadhi.gov.in/data/MRP_March17.pdf

8. http://www.medindia.net/drug-price/pantoprazole.htm

9. http://www.fiercepharma.com/special-report/top-20-genericscompanies-by-2014-revenue

10. http://www.dbsalliance.org/pdfs/GenericRx.pdf

11. www.medlineindia.com

12. www.drugsupdate.com

13. www.medindia.com

14. www.pharmacytimes.com

15. Mathew P (2015) Generic drugs review and experiences from south India. J Family Med Prim Care 4(3): 319-323.

16. Singhal GL, Kotwani A, Nanda A (2011) Jan aushadhi stores in India and quality of medicines there in. Int J Pharm Pharm Sci 3(1): 204-207.

17. www.medlineindia.com

18. www.drugsupdate.com

\section{9. www.medindia.com}

20. www.pharmacytimes.com

21. http://www.ncbi.nim.nih.gov/pubmed/22510171

22. www.medlineindia.com

23. www.consumerreport.org

24. www.drugsupdate.com

25. www.medindia.com

26. www.pharmacytimes.com

27.https://www.fda.gov/drugs/resourcesforyou/consumers / buyingusingmedicinesafely/understandingenericdrugs/ucm167991. htm

28.http://www.dbsalliance.org/pdfs/GenericRx.pdf accessed on $30 / 08 / 2017$

29. Jinhee K, Bonnie B, Williams AD (2013) Understanding Health Insurance Literacy: A Literature Review. Fam Consum Sci Res J 42(1): 3-13.

30. Ernst S, Judith M, Noor T, Florence M, Arthur TH, et al. (2012) The impact of health insurance in Africa and Asia a systematic review. Bull World Health Organ 90: 685-692.

31. http://www.apnapaisa.com/insurance/health-insurance-india/kyi. html

32.https://www.policybazaar.com/health-insurance/general-info/ articles/health-insurance-companies-in-india/

33. Hari DM, Prasant P, Steffi CS, Naushad Ali (2013) An overview of bioavailability and bioequivalence study in human subjects. Int J Pharm Pharm Sci 3(2): 79-87.

\section{Your next submission with Juniper Publishers will reach you the below assets}

- Quality Editorial service

- Swift Peer Review

- Reprints availability

- E-prints Service

- Manuscript Podcast for convenient understanding

- Global attainment for your research

- Manuscript accessibility in different formats

( Pdf, E-pub, Full Text, Audio)

- Unceasing customer service

Track the below URL for one-step submission https://juniperpublishers.com/online-submission.php 